\title{
Wolf-Hirschhorn Syndrome Associated with an Unusual Abnormality of Chromosome No. $4^{\star}$
}

\author{
MIRIAM G. WILSON, $†$ JOSEPH W. TOWNER, and LYNN D. NEGUS \\ From University of Southern California School of Medicine, Los Angeles, California, U.S.A.
}

A clinically recognizable syndrome associated with deletion of the short arms of chromosome B4 was first reported by Wolf et al. (1965) and Hirschhorn, Cooper, and Firschein (1965). Twelve patients have been reported (Leão et al., 1967; Carter, Baker, and Hayman, 1969; Giorgi, Ceccarelli, and Paci, 1965; Hijmans and Shearin, 1965; Hirschhorn et al., 1965; Miller et al., 1966a, b; Pfeiffer, 1968; Sidbury, Schmickel, and Gray, 1964; Taylor, 1968; Wolf et al., 1965), including three who were thought to represent an atypical 'cri du chat' syndrome (Giorgi et al., 1965; Hijmans and Shearin, 1965; Sidbury et al., 1964). Though the syndrome shows similarity to 'cri-du-chat', there are important differences in a number of the phenotypic characteristics, such as the midline cranial defects and the lack of a cat-cry. In addition, autoradiography studies in six cases (Leão et al., 1967; Miller et al., 1966a, b; Pfeiffer, 1968; Wolf et al., 1965) have shown that the Wolf-Hirschhorn syndrome is associated with deletion of the short arms of chromosome No. 4; whereas, in 'cri-duchat' the short arms of No. 5 are deleted.

Our patient shows the phenotype associated with deletion of the short arms of chromosome No. 4; however, the karyotype from this patient shows elongated short arms of chromosome No. 4. This structural abnormality has not been previously described in this syndrome; nor to our knowledge has a similar abnormal chromosome No. 5 been found in 'cri-du-chat'. Assuming that the WolfHirschhorn phenotype is a deletion syndrome, we postulate that the deletion of the abnormal chromosome No. 4 may be masked by translocation chromosome material.

Received 6 November 1969.

$\star$ This study was supported by project grant 322 from the Children's Bureau.

† Present address: Department of Pediatrics, Los Angeles CountyUniversity of Southern California Medical Center, 1200 North State
Street, Los Angeles, California 9,0033, U.S.A.

\section{Case Report}

The patient (DW 271267) is a Caucasian male, the first-born child in a marriage of a 39-year-old mother and a 41-year-old father. Both parents are normal in appearance except that after the birth of this child the mother had a radical mastectomy and oophorectomy for breast carcinoma. By a previous marriage the mother had been pregnant on four occasions; two pregnancies resulted in spontaneous abortions and two in normal term girls. The father's children from a former marriage were five live girls, a male infant who died at birth, and a stillborn female without congenital anomalies. There is no family history of congenital anomalies, mental retardation, neuromuscular disorders, infertility, or repeated abortions. The mother had taken an oral contraceptive consisting of norethindrone and mestranol during the first two months of the pregnancy. Otherwise, the pregnancy was uneventful up to 36 weeks when this child was born after spontaneous labour and normal delivery.

The child weighed $2060 \mathrm{~g}$. and had multiple major abnormalities including cleft lip and palate. Total body length was $48 \mathrm{~cm}$.; head circumference was $30 \mathrm{~cm}$. All the body measurements were less than the 10th percentile for 36 weeks' gestation (Lubchenco et al., 1963); in addition, the head circumference was disproportionately small in relation to the child's weight and length. During early infancy the child was not vigorous; he ate poorly and gained weight slowly. At 6 months of age his bilateral cleft lip was repaired.

At 9 months of age the infant was clearly retarded in growth and development. He seemed to see and hear, but was not able to sit, roll, or reach for objects. His weight $(6.44 \mathrm{~kg}$.) and length $(66 \mathrm{~cm}$.) were at about the 3 rd percentile for age, while his head circumference of $38.5 \mathrm{~cm}$. was well below the $3 \mathrm{rd}$ percentile.

The head and facial abnormalities were as follows: facial and cranial asymmetry, scanty growth of hair on head and eyebrows, microcephaly, prominent glabella, with an overlying flat flame naevus, hypertelorism, antimongoloid palpebral slants, prominent eyes and lid ptosis, strabismus and nystagmus, speckled irises (Brushfield's spots), large low-set ears with little cartilage in the pinnae, deep pin-point pre-auricular dimples, broad misshapen nose with wide nasal septum, repaired 
bilateral cleft lip, a midline cleft of the anterior threequarters of the hard palate, and micrognathia. Other anomalies were clinodactyly of the fifth fingers, contractures of the great toes, hypospadias (first degree), narrow buttocks, and dimples over the posterior shoulders, elbows, knuckles, and sacrum (Fig. 1). His cry was high pitched but did not resemble that of a cat, nor at any time had he been heard to cry like a cat.

At $1 \frac{1}{2}$ years of age, this child has obvious mental and growth retardation, and an unusual appearance. His height and weight are less than the 10th percentiles; his head circumference is less than the 3rd percentile for age. He has only recently begun to sit propped and reach in a crude manner for toys. Since 1 year of age he has had minor motor and myoclonic seizures which are poorly controlled by medication.
Cytogenetic studies. Chromosome preparations from peripheral blood and fibroblast cultures of the patient show a karyotype of $46, X Y, 4 p+$ (Table I). A

\section{TABLE I}

CHROMOSOME ANALYSES FROM PATIENT AND PARENTS

\begin{tabular}{l|c|c}
\hline & $\begin{array}{c}\text { No. of } \\
\text { Cells } \\
\text { Analysed }\end{array}$ & Analysis \\
\hline \begin{tabular}{l|l} 
Patient \\
Leucocyte cultures (2)
\end{tabular} & 52 & $46, \mathbf{X Y}, \mathrm{Bp}+$ \\
$\begin{array}{c}\text { Fibroblast culture } \\
\text { Lether }\end{array}$ & 25 & $46, \mathrm{XY}, \mathrm{Bp}+$ \\
$\begin{array}{c}\text { Father } \\
\text { Leucocyte culture }\end{array}$ & 25 & $46, \mathrm{XX}$ \\
\hline
\end{tabular}

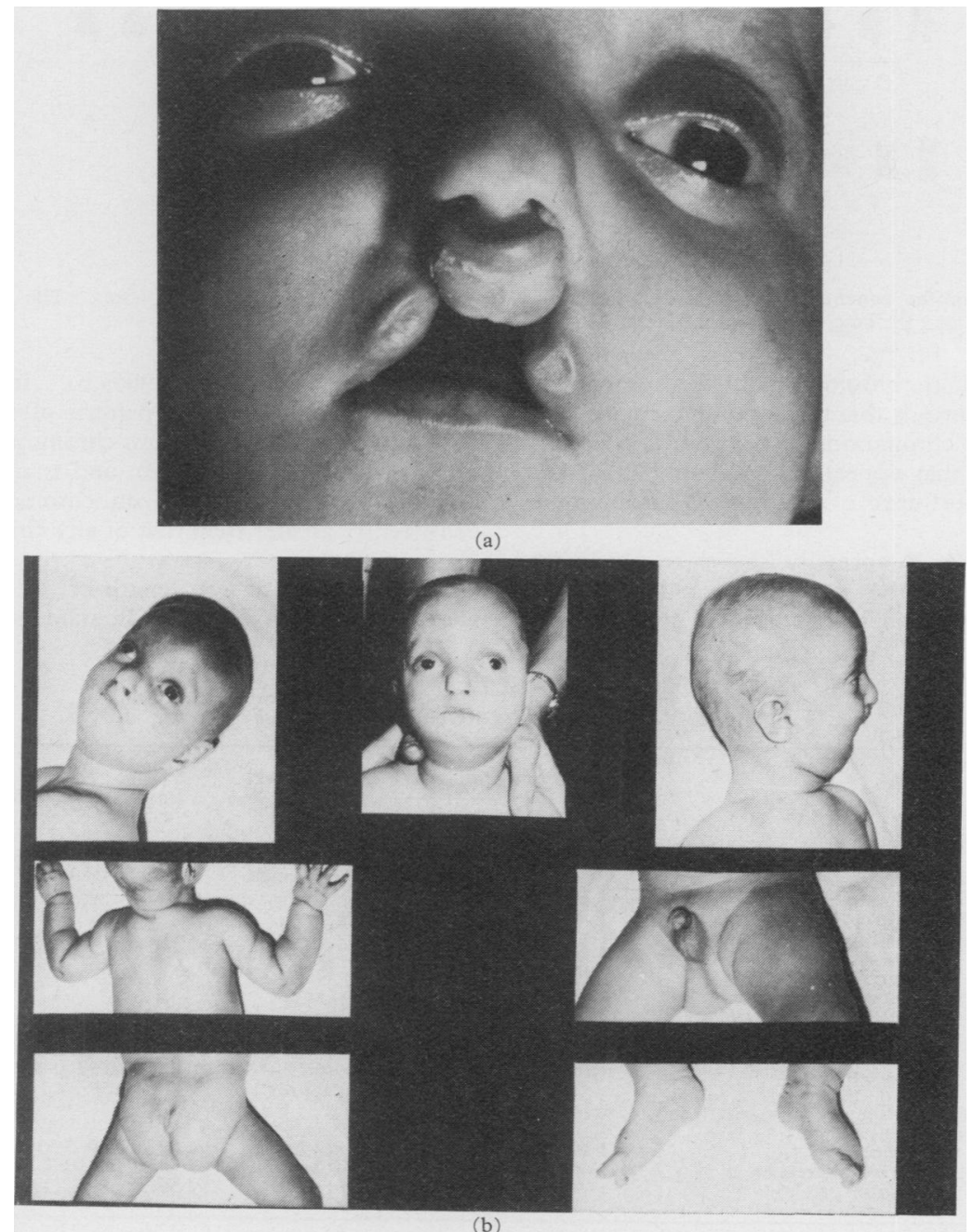

Fig. 1. Patient. (a) At 6 months, before repair of cleft lip. Note speckled irises. (b) At 9 months. Cleft lip has been repaired. Note facial features as described in text, large simple ear, narrow pelvis, hypospadias, contractures of the great toe, and dimples over
the shoulders; elbows, knuckles, and sacrum. 
FIG. 2. Karyotype of the patient. The arrow indicates the $B$ chromosome with elongated short arms. The short arms of the other B chromosomes and the long arms of all the B chromosomes are normal by measurement.

consistent finding in the chromosome analysis from blood and fibroblast cultures is that the B group contains three normal appearing chromosomes; the fourth has elongated short arms that appear to be about 30 to $40 \%$ longer than the short arms of the other B chromosomes (Fig. 2).

Chromosome No. 4 normally shows relatively late DNA replication of the long arms and, therefore, heavier autoradiographic labelling than does chromo- some No. 5 (Miller et al., 1966a,b). In our patient the autoradiographic labelling pattern of the abnormal B chromosome is consistent with chromosome No. 4, in 35 of 42 analysed cells (Fig. 3), and is questionable in 7 cells. The label intensity on chromosome No. 4 is consistently greater than that of any chromosome in the C group.

Measurements of arm length of the B chromosomes were obtained from autoradiograms of 37 cells and

TABLE II

MEASUREMENTS OF B GROUP CHROMOSOMES

\begin{tabular}{|c|c|c|c|c|c|c|}
\hline & \multicolumn{4}{|c|}{ Chromosome No. 4 (late labelling) } & \multirow{2}{*}{\multicolumn{2}{|c|}{$\underset{\text { (early labelling) }}{\text { Chromosome No. } 5}$}} \\
\hline & \multicolumn{2}{|c|}{$\begin{array}{l}\text { With Elongated } \\
\text { Short Arm }\end{array}$} & \multicolumn{2}{|r|}{ Other } & & \\
\hline & Mean & (Range) & Mean & (Range) & Mean & (Range) \\
\hline 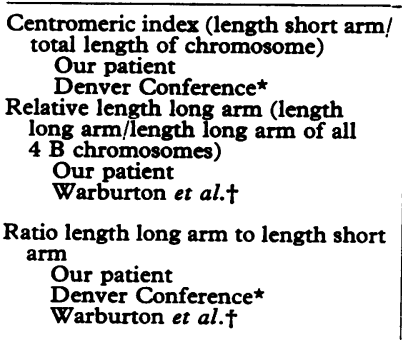 & $\begin{array}{l}\frac{0.34}{-} \\
0.26\end{array}$ & $\begin{array}{l}(0.27-0.38) \\
(0.23-0.29)\end{array}$ & $\begin{array}{l}2.59 \\
2.59\end{array}$ & $\begin{array}{l}(0.24-0.35) \\
(0 \cdot 25-0.28) \\
\\
(0.22-0.29) \\
(0 \cdot 22-0 \cdot 30) \\
\text { approx. }) \\
\\
(2 \cdot 2-3 \cdot 2) \\
(2 \cdot 6-2 \cdot 9)\end{array}$ & $\begin{array}{l}0.25 \\
0 \cdot 243 \\
\\
2.52 \\
2 \cdot 56\end{array}$ & $\begin{array}{l}(0 \cdot 22-0.33) \\
(0 \cdot 24-0.30) \\
\\
(0 \cdot 21-0.30) \\
(0 \cdot 22-0 \cdot 28 \\
\text { approx. }) \\
(2 \cdot 0-3 \cdot 5) \\
(2 \cdot 4-3 \cdot 2)\end{array}$ \\
\hline
\end{tabular}

\ Measurements from Denver Conference (1960) were from 6 laboratories. No autoradiographic studies were done.

† Measurements from Warburton et al. (1967) include normal B chromosomes and deleted B chromosomes when deleted arm is not involved in the ratios above. 


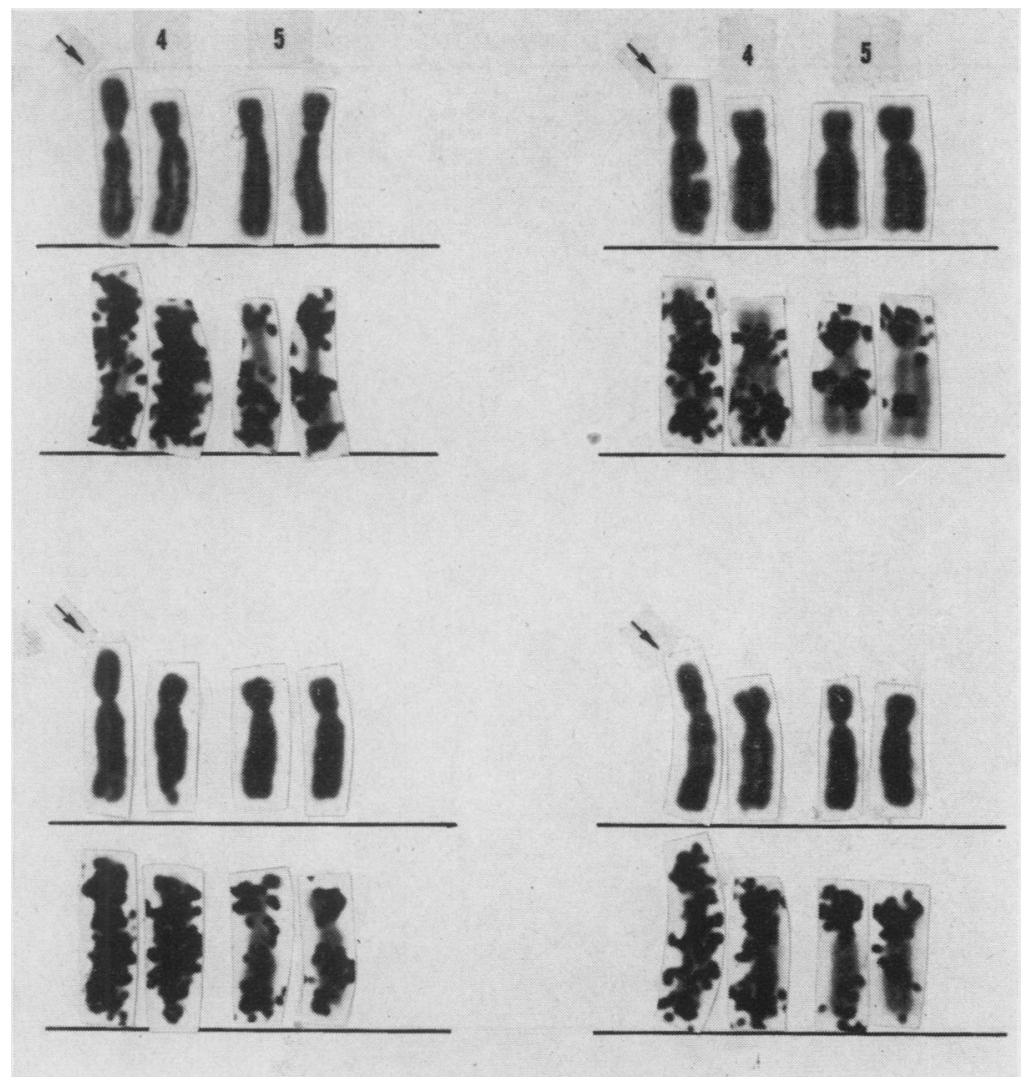

Fig. 3. Autoradiography of the B group chromosomes. Chromosome No. 4 shows heavy labelling of the long arms. Chromosome No. 5 shows lighter labelling.

compared with standards for normal B group chromosomes, as reported by the Denver Conference (1960) and Warburton et al. (1967) (Table II). The relative length of the short arm of the abnormal chromosome No. 4 is significantly increased, as determined by comparing its centromeric index (ratio of length short arm to total length of the chromosome) with the other B chromosomes and normal standards. The relative lengths of the short arm of the non-affected chromosome No. 4 and chromosomes No. 5 are normal, as are the lengths of the long arm of all the $\mathrm{B}$ chromosomes. These observations indicate that the only unusual feature of the B group of chromosomes in our patient is the increased length of the short arm of one chromosome No. 4.

Karyotypes prepared from peripheral blood cultures of the child's parents are normal.

Other investigative studies. Palmar prints illustrated in Fig. 4 show an incomplete transverse crease bilaterally, a ridge count of 82 (which is lower than one standard deviation for normal males), and a slightly raised distal triradius $\left(t^{\prime}\right)$. Transverse palmar creases are found in the majority of patients with Wolf-Hirschhorn syndrome (Table III). Low ridge counts in this syndrome have been reported by Wolf et al. (1965) and Warburton and Miller (1967), though the latter investigators found no significant differences in dermatoglyphs between 'cri-du-chat' and Wolf-Hirschhorn syndromes. Hypoplastic ridges (Leão et al., 1967; Hijmans and Shearin, 1965; Miller et al., 1966a; Pfeiffer, 1968; Taylor, 1968; Wolf et al., 1965), $\mathbf{t}^{\prime}$ triradius (Hijmans and Shearin, 1965; Hirschhorn et al., 1965; Wolf et al., 1965), and a high proportion of finger tip arches (Hirschhorn et al., 1965) have been reported.

Buccal smears from the child show negative sex chromatin. Complete blood typing of the child and his parents shows no deletion effect. As reported previously (Haddad et al., 1969), immunoglobulins of this patient are normal, as are those of the parents. Concentrations of haemoglobins $F$ and $A_{2}$, determined by column chromatography, are normal.

Radiological findings in this patient confirm the clinical findings of microcephaly, cranial and facial asymmetry, growth retardation, and decreased muscle mass. There are also a narrow pelvis and hypoplastic pubic bones. There are no vertebral abnormalities. An intravenous urogram is normal. An electroencephalogram shows generalized and frequent paroxysmal, high 
TABLE IV

CLINICAL FEATURES OF WOLF-HIRSCHHORN SYNDROME

\begin{tabular}{|c|c|c|c|c|c|c|c|c|c|c|c|c|c|}
\hline & $\begin{array}{l}\text { Present } \\
\text { Patient }\end{array}$ & $\begin{array}{l}\text { Wolf } \\
\text { et al. } \\
(1965)\end{array}$ & $\begin{array}{l}\text { Hirsch- } \\
\text { horn } \\
\text { et al. } \\
\text { (1965) }\end{array}$ & $\begin{array}{l}\text { Sidbury } \\
\text { et al. } \\
(1964)\end{array}$ & $\begin{array}{l}\text { Hijmans } \\
\text { and } \\
\text { Shearin } \\
(1965)\end{array}$ & $\begin{array}{l}\text { Giorgi } \\
\text { et al. } \\
(1965)\end{array}$ & $\begin{array}{c}\text { Miller } \\
\text { et al. } \\
(1966 \mathrm{a})\end{array}$ & $\begin{array}{c}\text { Miller } \\
\text { et al. } \\
(1966 \mathrm{a})\end{array}$ & $\begin{array}{c}\text { Leão } \\
\text { et al. } \\
(1967)\end{array}$ & $\begin{array}{c}\text { Pfeiffer } \\
(1968)\end{array}$ & $\begin{array}{c}\text { Pfeiffer } \\
\text { (1968) }\end{array}$ & $\begin{array}{l}\text { Taylor } \\
(1968)\end{array}$ & $\begin{array}{l}\text { Carter } \\
\text { et al. } \\
(1969)\end{array}$ \\
\hline $\begin{array}{l}\text { Sex } \\
\text { Birthweight (g.) }\end{array}$ & $\underset{2060}{M}$ & $\underset{1750}{F}$ & $\underset{2240}{M}$ & $\dot{\mathbf{F}}$ & $\begin{array}{c}F \\
2160 \\
\text { (twin) }\end{array}$ & $\underset{2200}{F}$ & $\underset{1980}{M}$ & $\underset{2160}{M}$ & $\underset{1800}{M}$ & $\underset{1200}{F}$ & $\underset{1400}{M}$ & $\underset{1460}{M}$ & $\begin{array}{c}\mathrm{M} \\
1880\end{array}$ \\
\hline $\begin{array}{l}\text { Growth retardation } \\
\text { Mental retardation }\end{array}$ & $\begin{array}{l}+ \\
+\end{array}$ & $\begin{array}{l}+ \\
+\end{array}$ & $\begin{array}{l}+ \\
+\end{array}$ & + & $\begin{array}{l}+ \\
+\end{array}$ & + & $\stackrel{+}{+}$ & $\begin{array}{l}+ \\
+\end{array}$ & $\begin{array}{l}+ \\
+\end{array}$ & $\begin{array}{l}+ \\
+\end{array}$ & + & (Died at & (Died at \\
\hline Convulsions & $\stackrel{+}{+}$ & $\begin{array}{l}+ \\
+\end{array}$ & + & + & + & $\begin{array}{l}+ \\
+\end{array}$ & + & + & $\begin{array}{l}+ \\
+\end{array}$ & $\begin{array}{l}+ \\
+\end{array}$ & + & & (1 mth.) \\
\hline $\begin{array}{l}\text { Microcephaly } \\
\text { Cranial asymmetry }\end{array}$ & $\begin{array}{l}+ \\
+\end{array}$ & + & + & & $\stackrel{+}{+}$ & $\begin{array}{l}+ \\
t\end{array}$ & + & + & + & + & + & + & + \\
\hline Prominent glabella & + & + & + & & + & $\begin{array}{l}+ \\
+\end{array}$ & & + & $\begin{array}{l}+ \\
+\end{array}$ & $\begin{array}{l}+ \\
+\end{array}$ & $\begin{array}{l}+ \\
+\end{array}$ & $\begin{array}{l}+ \\
+\end{array}$ & + \\
\hline $\begin{array}{l}\text { Midline scalp defects } \\
\text { Haemangioma on brow }\end{array}$ & + & $\stackrel{+}{+}$ & + & & & & & & + & & & & \\
\hline $\begin{array}{l}\text { Hypertelorism } \\
\text { Strabismus }\end{array}$ & $\begin{array}{l}+ \\
+\end{array}$ & + & $\begin{array}{l}+ \\
+\end{array}$ & + & $\begin{array}{l}+ \\
+\end{array}$ & + & $\begin{array}{l}+ \\
+\end{array}$ & $\begin{array}{l}+ \\
+\end{array}$ & + & $\begin{array}{l}+ \\
+\end{array}$ & $\begin{array}{l}+ \\
+\end{array}$ & + & + \\
\hline $\begin{array}{l}\text { Prominent eyes } \\
\text { Epicanthus }\end{array}$ & + & & & & + & & & & $\begin{array}{l}+ \\
+\end{array}$ & + & $\begin{array}{l}+ \\
+\end{array}$ & & + \\
\hline Ptosis & + & + & & & & & & & + & & & & \\
\hline Antimongoloid slants & + & & & + & + & & & + & 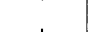 & & & & \\
\hline $\begin{array}{l}\text { Iris derects } \\
\text { Low ears with little }\end{array}$ & + & + & + & + & & + & & & + & & & + & + \\
\hline $\begin{array}{l}\text { cartilage } \\
\text { Broad misshapen nose }\end{array}$ & $\stackrel{+}{+}$ & $\begin{array}{l}+ \\
+\end{array}$ & + & $\begin{array}{l}+ \\
+\end{array}$ & + & + & + & \pm & + & + & + & + & + \\
\hline $\begin{array}{l}\text { Broad, missnapen nose } \\
\text { Cleft lip or palate } \\
\text { (Other palate } \\
\text { deformity) }\end{array}$ & $\begin{array}{l}+ \\
+\end{array}$ & $\begin{array}{l}+ \\
+\end{array}$ & + & (High) & $\begin{array}{l}+ \\
+\end{array}$ & $\begin{array}{l}+ \\
+\end{array}$ & & + & $\begin{array}{c}+ \\
\text { (High) }\end{array}$ & + & $\begin{array}{c}+ \\
\text { (Bifid }\end{array}$ & $\begin{array}{l}+ \\
+\end{array}$ & $\begin{array}{l}+ \\
+\end{array}$ \\
\hline Micrognathia & + & & + & \pm & + & + & & & & + & $\begin{array}{l}\text { uvula) } \\
+\end{array}$ & + & \\
\hline $\begin{array}{l}\text { Cryptorchidism } \\
\text { Inguinal hernia }\end{array}$ & & $\begin{array}{l}\mathbf{F} \\
\mathbf{F}\end{array}$ & & $\begin{array}{l}\mathbf{F} \\
\mathbf{F}\end{array}$ & $\vec{F}$ & $\mathbf{F}$ & & + & + & $\mathbf{F}$ & + & + & \\
\hline Hypospadias & + & $\mathbf{F}$ & + & $\mathbf{F}$ & $\mathbf{F}$ & $\mathbf{F}$ & & + & $\begin{array}{l}+ \\
+\end{array}$ & $\mathbf{F}$ & + & + & + \\
\hline Sacral dimple & + & & & & & & + & + & + & & & & \\
\hline $\begin{array}{l}\text { Flexion deformities } \\
\text { of fingers }\end{array}$ & + & + & & & & & + & + & + & & & + & \\
\hline $\begin{array}{l}\text { Clinodactyly } \\
\text { Transverse palmar }\end{array}$ & + & & & & + & & & & & & & & + \\
\hline $\begin{array}{l}\text { crease } \\
\text { Malformed great toe }\end{array}$ & $\frac{ \pm}{t}$ & $\begin{array}{l}+ \\
+\end{array}$ & \pm & & + & & & \pm & $\stackrel{+}{t}$ & & & + & + \\
\hline & & & & & & & & & & & & & \\
\hline
\end{tabular}

amplitude spikes. Haemogram, urinalysis, routine blood chemistries, and electrocardiograms are normal.

\section{Discussion}

A presumptive diagnosis of Wolf-Hirschhorn syndrome in this patient is possible on clinical grounds because of the striking similarity of phenotype to other reported cases. These patients have an unusual appearance, primarily due to the generally asymmetrical and misshapen cranial and facial anatomy. Frequently found are cleft lip and palate, hypertelorism and eye abnormalities such as
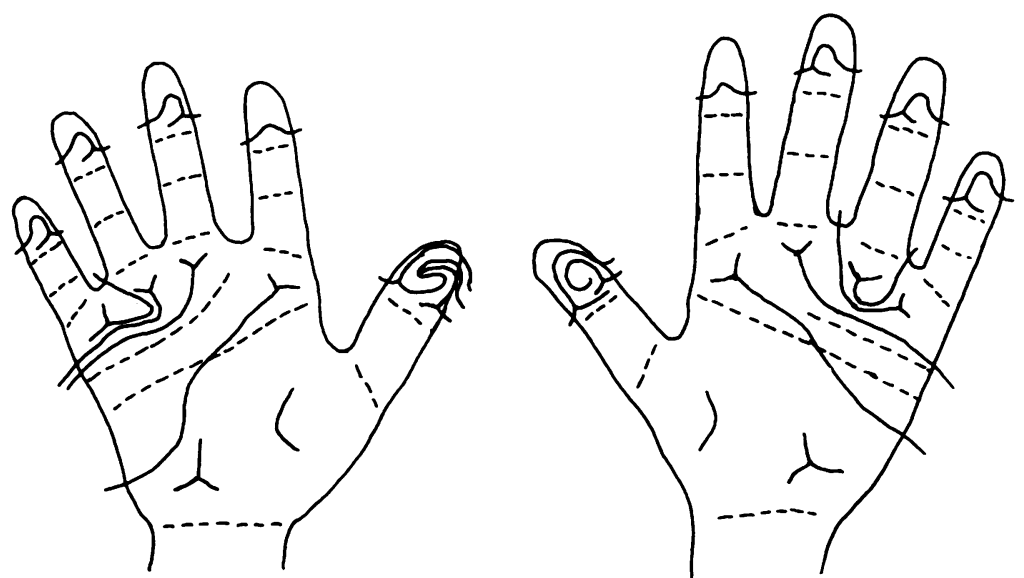

Fig. 4. Palmar prints of the patient. Note bilateral incomplete transverse palmar crease. 
prominent eyes, strabismus, and iris defects such as coloboma, ectopic pupil, and coarse iris. Relatively consistent findings have been dimpling of the skin over the sacrum and elsewhere, and hypospadias in the male. Severe growth and mental retardation have invariably been present; convulsions are frequent; and a variety of skeletal anomalies have been reported (Table III).

Other syndromes associated with chromosome abnormalities show some of these features such as retardation, epicanthi, slanted palpebral fissures, simian creases, and contractures of the fingers and toes. Midline cranial and facial defects, microcephaly, and brow haemangioma are seen in Patau's syndrome associated with trisomy $\mathrm{D}$; skin dimples, in the syndrome associated with partial deletion of the long arm of 18; finger contractures, in Edwards' syndrome associated with trisomy $\mathrm{E}$; and clinodactyly of the fifth finger, in Down's syndrome. Our patient shows depigmented speckling of the peripheral iris (Brushfield's spots) as distinct as that found in Down's syndrome.

The syndrome presenting a major problem in differential diagnosis is 'cri-du-chat' since there are features common to both, such as microcephaly, antimongoloid slants, hypertelorism, and retardation. Marked facial and cranial distortion and midline cranial defects are restricted to Wolf-Hirschhorn syndrome. Likewise, iris deformities, hypospadias in the male, and skin dimples are not part of the 'cri-du-chat' syndrome. Further, in Wolf-Hirschhorn syndrome, a cat-cry is not present. The phenotypic differences and the autoradiography studies identifying a late labelling deleted B chromosome in Wolf-Hirschhorn syndrome and an earlier labelling deleted $B$ chromosome in 'cri-du-chat' favour the conclusion that these are indeed two different syndromes, rather than variable manifestations of the same condition.

Error in diagnosis may result from attempts to classify into already described syndromes which are based on anatomical features alone; for example, one instance of Hallermann Streiff François syndrome, a facial mandibular dysostosis, is reported in which there is a partial deletion of the short arm of a B-group chromosome (Carones, 1961).

In 11 reported cases of Wolf-Hirschhorn syndrome (Leão et al., 1967; Giorgi et al., 1965; Hijmans and Shearin, 1965; Hirschhorn et al., 1965; Miller et al., 1966a, b; Pfeiffer, 1968; Sidbury et al., 1964; Taylor, 1968; Wolf et al., 1965) the chromosomal abnormality is a partial deletion of the short arms of a B chromosome; in 6 instances, the chromosome was identified as No. 4 by autoradiography studies (Leão et al., 1967; Miller et al., 1966a, b; Pfeiffer, 1968; Wolf et al., 1965). A ring chromosome B, presumptively No. 4 on the basis of the phenotype, is now described with WolfHirschhorn syndrome (Carter et al., 1969). As in our case, the parents who have been examined show normal karyotypes (Leão et al., 1967; Carter et al., 1969; Hijmans and Shearin, 1965; Hirschhorn et al., 1965; Miller et al., 1966a; Pfeiffer, 1968).

The origin of the additional chromosome material is unknown. Assuming that the Wolf-Hirschhorn syndrome is associated with a partial deletion of the short arms of No. 4, we suggest that, in our patient, whose features are characteristic of Wolf-Hirschhorn syndrome, a non-reciprocal translocation has occurred in which a portion of another chromosome has been translocated to the short arm of chromosome No. 4, thus obscuring the critical deletion. The translocated material may be derived from a chromosome where a deletion is undetectable, such as a member of the $\mathrm{C}$ group. According to this theory, there is deletion of No. 4, but no gene duplication.

As another possibility, the abnormal chromosome may have resulted from a reciprocal translocation between a No. 4 and another chromosome during gametogenesis. After fertilization, the zygote contained the abnormal No. 4, but not the other chromosome participating in the translocation. There are both gene duplication and deletion in this instance. Still another possibility is that the morphologically altered chromosome is an unbalanced cross-over segregation product involving a chromosome No. 4 with a pericentric inversion. This assumes that one of the parents is an undetected mosaic for an abnormal chromosome No. 4, or the inversion occurred during gametogenesis. In this instance, as above, the abnormal chromosome No. 4 in the child represents gene duplication as well as deletion.

The morphology of the affected chromosome is described as $4 p+$, according to the Chicago notation (Chicago Conference, 1966); the phenotype may be described by the eponym, Wolf-Hirschhorn syndrome.

\section{Summary}

In summary, the Wolf-Hirschhorn syndrome may be recognized on clinical grounds. With the exception of our patient, other cases have been associated with karyotypes showing unusually short short arms of chromosome No. 4, consistent with an intercalary deletion or, in one instance, a ring chromosome. In the case described here, the short arms of chromosome No. 4 are elongated. A 
deletion of the short arms of chromosome No. 4, responsible for the syndrome, may be obscured by translocation of other chromosome material onto this chromsome. An unbalanced cross-over segregation product from a pericentric inversion is another possibility.

We are grateful to the following who have contributed to the study of this patient: Mr. Paul Brager and Mr. William George for technical assistance; Mr. Paul Brager for description of the dermatoglyphs; Dr. Zack Haddad, for determination of immunoglobulins; Dr. Philip Sturgeon, for blood typing; Dr. Leslie Holve, for photographs; and the numerous physicians who participated in the medical management of this child.

\section{REFERENCES}

Carones, A. V. (1961). Syndrome dyscephalique de François. Ophthalmologica, 142, 510-518.

Carter, R., Baker, E., and Hayman, D. (1969). Congenital malformations associated with a ring 4 chromosome. Fournal of Medical Genetics, 6, 224-227.

Chicago Conference: Standardization in Human Cytogenetics (1966). Birth Defects: Original Article Series II, 2. The National Foundation-March of Dimes, New York.

Denver Conference (1960). A proposed standard system of nomenclature of human mitotic chromosomes. Lancet, 1, 1063-1065.

Giorgi, P. L., Ceccarelli, M., and Paci, A. (1965). Su un caso di sindrome del 'cri du chat' con peculiari anomalie fenotipiche, Minerva Pediatrica, 17, 1972-1975.

HLaddad, Z. H., Allen, R. F., Towner, J. W., and Wilson, M. G. (1969). IgA, IgM, and partial deletion of chromosome 18. Lancet, 1, 678.
Hijmans, J. C., and Shearin, D. B. (1965). Partial deletion of short arms of chromosome No. 5. American fournal of Diseases of Children, 109, 85-89.

Hirschhorn, K., Cooper, H. L., and Firschein, I. L. (1965). Deletion of short arms of chromosome 4-5 in a child with defects of midline fusion. Humangenetik, 1, 479-482.

Leão, J. C., Bargman, G. J., Neu, R. L., Kajii, T., and Gardner, L. I. (1967). New syndrome associated with partial deletion of short arms of chromosome No. 4. Fournal of the American Medical Association, 202, 434-437.

Lubchenco, L. O., Hansman, C., Dressler, M., and Boyd, E. (1963) Intrauterine growth as estimated from liveborn birthweight data at 24 to 42 weeks of gestation. Pediatrics, 32, 793-800.

Miller, O. J., Breg, W. R., Warburton, D., Miller, D. A., deCapoa, A., and Chutorian, A. M. (1966a). Deleted late-replicating chromosome 4/5. Lancet, 2, 105-106.

,,---1, Firschein, I. L., and Hirschhorn, K. (1966b). Alternative DNA replication patterns associated with long arm length of chromosomes 4 and 5 in the cri du chat syndrome. Cytogenetics, 5, 137-151.

Pfeiffer, R. A. (1968). Neue Dokumentation zur Abgrenzung eines Syndroms der Deletion des kurzen Arms eines Chromosoms nr. 4. Zeitschrift für Kinderheilkunde, 102, 49-61.

Sidbury, J. B., Jr., Schmickel, R. D., and Gray, M. (1964). Findings in a patient with apparent deletion of short arms on one of the B group chromosomes (Abstract). Fournal of Pediatrics, 65, 1098.

Taylor, A. I. (1968). Autosomal trisomy syndromes: A detailed study of 27 cases of Edwards' syndrome and 27 cases of Patau's syndrome. Fournal of Medical Genetics, 5, 227-252.

Warburton, D., and Miller, O. J. (1967). Dermatoglyphic features of patients with a partial short arm deletion of a B-group chromosome. Annals of Human Genetics, 31, 189-207.

-, Miller, D. A., Miller, O. J., Breg, W. R., deCapoa, A., and Shaw, M. W. (1967). Distinction between chromosome 4 and chromosome 5 by replication pattern and length of long and short arms. American fournal of Human Genetics, 19, 399-415.

Wolf, U., Reinwein, H., Porsch, R., Schröter, R., and Baitsch, H. (1965). Defizienz an den kurzen Armen eines Chromosoms nr. 4. Humangenetik, 1, 397-413. 